\title{
Correction to: Salivary glands in workers of Ruptitermes spp. (Blattaria, Isoptera, Termitidae, Apicotermitinae): a morphological and preoteomic approach
}

\author{
Ana Maria Costa-Leonardo ${ }^{1,2}$ - lago Bueno da Silva ${ }^{1}$. Vanelize Janei ${ }^{1} \cdot$ Silvana Beani Poiani ${ }^{2}$. \\ .José Roberto Aparecido dos Santos-Pinto ${ }^{2} \cdot$ Franciele Grego Esteves $^{2} \cdot$ Mario Sérgio Palma $^{2}$
}

Published online: 22 May 2021

(c) Springer-Verlag GmbH Germany, part of Springer Nature 2021

\section{Correction to: Cell and Tissue Research https://doi.org/10.1007/s00441-021-03469-w}

Due to an error, this article was published with an incorrect word in the title. The correct title of the article is "Salivary glands in workers of Ruptitermes spp. (Blattaria, Isoptera, Termitidae, Apicotermitinae): a morphological and proteomic approach", not "Salivary glands in workers of Ruptitermes spp. (Blattaria, Isoptera, Termitidae, Apicotermitinae): a morphological and preoteomic approach". Readers should be aware that this article may still be indexed under its previous, incorrect title.
Publisher's Note Springer Nature remains neutral with regard to jurisdictional claims in published maps and institutional affiliations.

The original article can be found online at https://doi.org/10.1007/ s00441-021-03469-w.

Ana Maria Costa-Leonardo

ana.costa-leonardo@unesp.br

1 Laboratório de Cupins, Departamento de Biologia Geral E Aplicada, Instituto de Biociências, Univ Estadual Paulista, UNESP, Campus Rio Claro, Avenida 24A, 1515, Bela Vista, Rio Claro, SP 13506-900, Brazil

2 Centro de Estudos de Insetos Sociais-CEIS, Instituto de Biociências, Univ Estadual Paulista, UNESP, Campus Rio Claro, Avenida 24A, 1515, Bela Vista, Rio Claro, SP 13506-900, Brazil 